\title{
Fibrosing colonopathy in children with cystic fibrosis
}

\begin{abstract}
Although intestinal strictures have been described in association with potassium chloride and nonsteroidal antiinflammatory drugs, fibrosing colonopathy (figure) appears to be a new entity in cystic fibrosis children. ${ }^{1}$

In the absence of effective pancreatic enzyme supplements, the intestinal malabsorption associated with cystic fibrosis is severe when compared to that associated with other conditions such as coeliac disease. Prior to the introduction of acid-resistant enzyme preparations in the UK in the early 1980s (Pancrease in 1983 and Creon in 1985) there were many cystic fibrosis patients who had persisting distressing gastrointestinal symptoms and signs associated with severe intestinal malabsorption. It was impossible to control the intestinal malabsorption of these patients, even with large doses of the older unprotected enzyme preparations and with the addition of additional strategies including gastric acid suppression using alkalis and $\mathrm{H} 2$ blockers. The quality of life of many of these patients was severely impaired; some had to restrict their fat intake in an attempt to reduce their unpleasant bowel symptoms. In doing so they reduced their energy intake and compromised their nutritional state.

The introduction of the acid-resistant enzyme preparations in the early 1980s improved the control of the
\end{abstract}

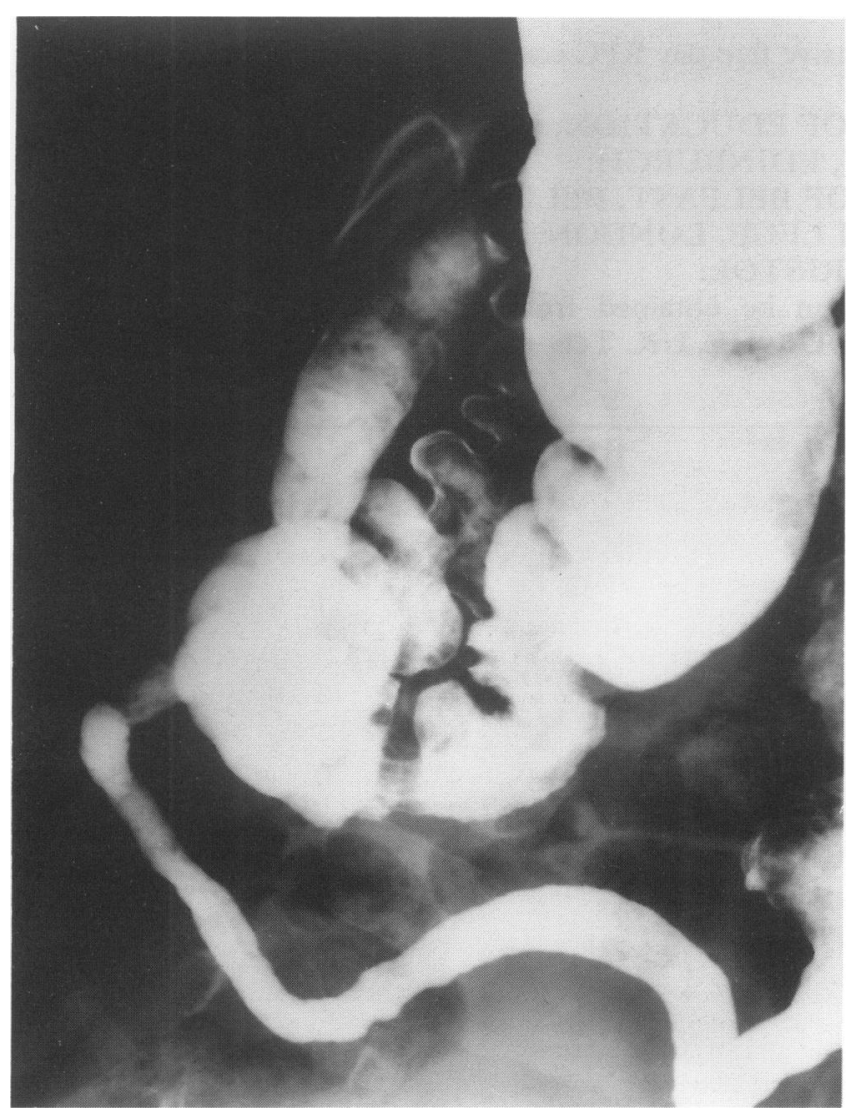

Figure A case of fibrosing colonopathy in a child with cystic fibrosis. intestinal absorption and permitted adequate control of the gastrointestinal symptoms in $90 \%$ of patients. Both the quality of life and nutrition of the patients were improved. However, some patients required large doses of the acidresistant enzymes to achieve adequate control of their symptoms and a reasonable fat absorption of over $85 \%$.

In 1992, the high strength enzyme preparations (Creon 25 000, Pancrease HL and Nutryzim 22) became available in the UK. The first clinical trials indicated that all the preparations were effective and permitted most patients to reduce significantly the number of capsules required to achieve a comparable degree of fat absorption. ${ }^{2,3}$ An occasional patient did not tolerate a particular preparation but seemed to respond to one of the others. So effective were the new preparations that many cystic fibrosis clinics had changed the majority of their patients to the highstrength enzymes by the end of 1993. However, some patients did not achieve a direct conversion in terms of lipase. Although the lipase content of the new preparations was three (Creon to Creon 25 000) to five (Pancrease to Pancrease HL) times that of the standard capsules, some patients required up to two-thirds as many high-strength capsules as standard capsules, ie, rather more than expected. Analysis of the enzyme intake of cystic fibrosis children showed that most patients had a higher lipase intake after transfer to the high-strength enzymes. There was only a $30 \%$ reduction in number of capsules/day while the number of units of lipase $/ \mathrm{kg} /$ day almost doubled. At the time, this absolute increase in enzyme dose was not considered of other than financial importance. The majority of patients were well pleased with the new high-strength enzymes. We did not consider the possibility of serious side-effects.

It was at this stage, between July and September 1993, that Ros Smyth and her colleagues in Liverpool observed the first children with colonic strictures which they reported in the Lancet in early $1994 .{ }^{1}$ In December 1993 the Committee on the Safety of Medicines (CSM) reported the occurrence of colonic strictures to clinicians and advised against the use of the high-strength preparations in childen until the cause of the new complication was determined. Also cystic fibrosis patients and their families were warned of the complication by the UK Cystic Fibrosis Trust. In November 1994 the CSM recommended that "unless special reasons exist, patients with cystic fibrosis should not use high potency pancreatins". Following the report of fibrosing colonopathy in two children taking high doses of a standard pancreatic preparation, ${ }^{4}$ the CSM recommended that "it would be prudent to avoid doses of pancreatic enzyme supplement in excess of 10000 units of lipase per kg per day, irrespective of the preparation".

Since the original description of fibrosing colonopathy, a great deal of information has been made available and there has been considerable progress in our understanding of the cause of the condition, both in the UK and North America. More patients have been described, and the association with the high-strength enzymes seems to have been established by both the UK and North American epidemiological studies. 
In November 1995 a symposium on this subject was held in Manchester, UK, and the proceedings of that meeting have now been published as a supplement to the Postgraduate Medical Journal. ${ }^{5}$

JM LITTLEWOOD

Regional Paediatric Cystic Fibrosis Unit, St Fames's University Hospital, Leeds LS9 7TF, UK
1 Smyth RL, van Velzen D, Smyth AR, Lloyd DA, Heaf DP. Strictures of ascending colon in cystic fibrosis and high-strength pancreatic enzymes. ancending colon in cystic

2 Bowler IM, Wolfe SP, Owens HM, Sheldon TA, Littlewood JM, Walters Bowler IM, Wolfe SP, Owens HM, Sheldon TA, Littlewood JM, Walters
MP. A double-blind lipase-for-lipase comparison of a high lipase and standard pancreatic enzyme preparation. Arch Dis Child 1993; 68: 227-30. Morrison G, Morrison J, Redmond A, Byers C, McCracken K, Dodge JA. Pancreatic enzyme supplements in cystic fibrosis. Lancet 1991; 338: 1596-7. Jones R, Franklin K, Spicer R, Beny J. Colonic strictures in children with cystic fibrosis on low strength pancreatic enzymes. Lancet 1995; 346: 449. 5 Littlewood JM, Hind CRK, eds. Fibrosing colonopathy in children with cystic fibrosis. Postgrad Med J 1996; 72 (suppl 2).

\section{THE WRIGHT FOUNDATION’S 'D’ DAY - 26 March 1996}

26 March 1996 is the Wright Foundation's ' $D$ ' day when many leisure centres throughout the UK will officially introduce patients to their first 'Exercise on Prescription'. There has been tremendous interest in the Wright Foundation's Medical Referral Programme to date. Leisure centres are extremely keen to gain approval and individuals are determined to gain the Referral Programme Consultant Qualification (RPC). In the build up to ' $D$ ' day, the Wright Foundation will ensure this happens.

The Wright Foundation have taken a massive step forward in achieving a healthier nation by launching the first UK-wide Medical Referral Programme - 23 November 1995.

Two years of extensive research and pilot programmes have enabled the Wright Foundation, in conjunction with leading medical, physiology and leisure professionals, and principal Universities, to develop and implement the first medically led medical referral programme. The programme represents a working partnership between general practitioners, medical professionals and sport/leisure centres and covers all the aspects necessary to ensure the health and safety of the referred patients and to maintain a high quality of patient care and therapy.

Places are now available for intensive five-day RPC courses being held at the following Universities in 1996:

MORAY HOUSE INSTITUTE OF EDUCATION, HERIOT-WATT UNIVERSITY, EDINBURGH:

4 March THE QUEEN'S UNIVERSITY OF BELFAST, BELFAST: $11 \mathrm{March}$ ST MARY'S UNIVERSITY COLLEGE, LONDON: 18 March UNIVERSITY OF BRISTOL, BRISTOL: $\quad 25$ March Details and further information can be obtained from Dianne Barr at the Wright Foundation, PO Box 159, Dundee DD1 9HE, UK. Tel: +44 1382 451188; Fax: + 441382 451163. 